\title{
Kondycja finansowa samorządu terytorialnego w Polsce jako czynnik stymulujący innowacyjność gospodarki
}

Współczesny rozwój gospodarki opartej na wiedzy polega na jej intensywnym wykorzystaniu, skutkującym szybszym generowaniem postępu techniczno-organizacyjnego. Wykorzystywanie w gospodarce posiadanych zasobów wiedzy oraz tworzenie nowych wymaga współdziałania wielu uczestników procesu gospodarczego, szczególnie tych, którzy są odpowiedzialni za kształtowanie odpowiedniej infrastruktury i tworzenie instytucjonalnych warunków sprzyjających rozwojowi gospodarczemu. Warunki te określają źródła endogenicznego rozwoju regionalnego opartego na wewnętrznym kapitale materialnym i ludzkim danej jednostki terytorialnej. Współcześnie kształtujące się sieci współpracy tworzą zbiór relacji między wieloma uczestnikami procesu gospodarczego. Ważną rolę odgrywają w nich - obok przedsiębiorstw, licznych organizacji konsultingowych i usługowych, instytucji badawczych i finansowych - administracja rządowa i samorządy terytorialne wszystkich poziomów (Domański, Marciniak 2003). Zadaniem władz publicznych jest stymulowanie wszystkich czynników odpowiedzialnych za rozwój nauki i badań, doskonalenie kadr i aplikowanie wysokiej techniki w przedsiębiorstwach uczącego się regionu (Florida 2000). Najczęściej spotykanym postulatem jest tworzenie regionalnego systemu innowacji, a więc budowanie instytucji publicznych działających wspólnie na rzecz stymulowania rozwoju technicznego gospodarki. Administracja ponadto powinna wspierać powstawanie sieci współpracy między instytucjami naukowymi, eksperckimi i gospodarczymi.

W artykule przedstawiono ocenę sytuacji finansowej jednostek samorządu terytorialnego w Polsce według ich podstawowych typów, tj. gmin, powiatów i województw. Zaprezentowano główne zagadnienia dotyczące wyników operacyjnych samorządów i ich struktur dotyczących dochodów, wydatków (w tym głównie inwestycyjnych), zadłużenia i deficytu budżetowego na podstawie wykonania budżetów głównie w latach 2005-2010. Przeprowadzone analizy dokonano w układzie wszystkich poziomów samorządu terytorialnego i jego poszczególnych typów. Z uwagi na obszerność badanego zagadnienia analizy przestrzenne przeprowadzono $\mathrm{w}$ odniesieniu do gmin i miast na prawach powiatu w układzie województw w 2009 r. Przyjęcie za punkt odniesienia powyższego roku wynikało z dostępności porównywalnych danych. 


\section{SAMORZĄD TERYTORIALNY A INNOWACYJNA GOSPODARKA}

Działania władz samorządowych w budowaniu innowacyjnej gospodarki powinny być głównie skierowane na wspieranie aktywności lokalnych przedsiębiorców, rozwój badań i nauki oraz edukacji, gdyż takie warunki sprzyjają powstawaniu innowacji w gospodarce. Wspieranie i tworzenie tych korzystnych uwarunkowań dla innowacji ze strony samorządu terytorialnego uzależnione jest jednak od jego dobrej kondycji finansowej.

Rolą władz publicznych w budowaniu współczesnej usieciowionej gospodarki jest m.in. tworzenie środowiska sprzyjającego powstawaniu innowacji. Dokonuje się to głównie przez kreowanie warunków korzystnych dla przedsiębiorczości poprzez:

- rozwój infrastruktury;

- budowanie klimatu inwestycyjnego;

- stymulowanie procesów współpracy, kooperacji w regionie;

- profesjonalną, sprawną i przyjazną administrację.

Ważnym działaniem samorządu terytorialnego jest także tworzenie partnerskich relacji i komunikowanie współczesnych trendów rozwoju. Do tego zespołu działań należą m.in. (Romanowski 2011):

- przejrzysta polityka wspierania przedsiębiorczości,

- promowanie właściwych sposobów współdziałania,

- wskazywanie źródeł finansowania,

- promowanie postaw proekologicznych, itp.

Władze samorządowe w większości przypadków dostrzegają swoje znaczenie w tworzeniu warunków dla innowacyjności. Z jednej strony samorządy województw zgodnie z przypisanymi im ustawowymi zadaniami opracowują Regionalne Strategie Innowacji. Z drugiej strony - wykazują aktywną postawę, przejawiającą się m.in. w strukturze zawartych umów w ramach 16 Regionalnych Programów Operacyjnych (RPO). Jednymi z najważniejszych kierunków wsparcia, według stanu na 31.07.2010 r., są projekty skierowane na badanie i rozwój technologiczny, innowacje i przedsiębiorczość. Udział zawartych przez samorządy w tym obszarze umów w ramach wszystkich 16 RPO wyniósł 23\%. (ryc. 1).

Szczególnym przypadkiem aktywnego działania samorządu terytorialnego w budowaniu innowacyjnej gospodarki jest finansowe wspieranie ze środków publicznych różnorodnych instytucji prorozwojowych. Należą do nich np. centra transferu technologii, parki technologiczne i inkubatory, które funkcjonują na styku biznesu i sfery badawczo-rozwojowej, a także aktywnie współpracują z samorządem i wspierają rozwój przedsiębiorczości, często związanej z branżami innowacyjnymi (Brezdeń, Drozdowska, Spallek 2010). Właściwe funkcjonowanie wspomnianych instytucji i realizowanie przez nie celów gospodarczych wymaga odpowiednich środków finansowych. Ich uzyskiwanie na drodze komercyjnej nie zawsze jest wystarczające. Wówczas niezbędne jest wspieranie ich działalności ze środków publicznych, których dysponentami są w większości samorządy terytorialne. 

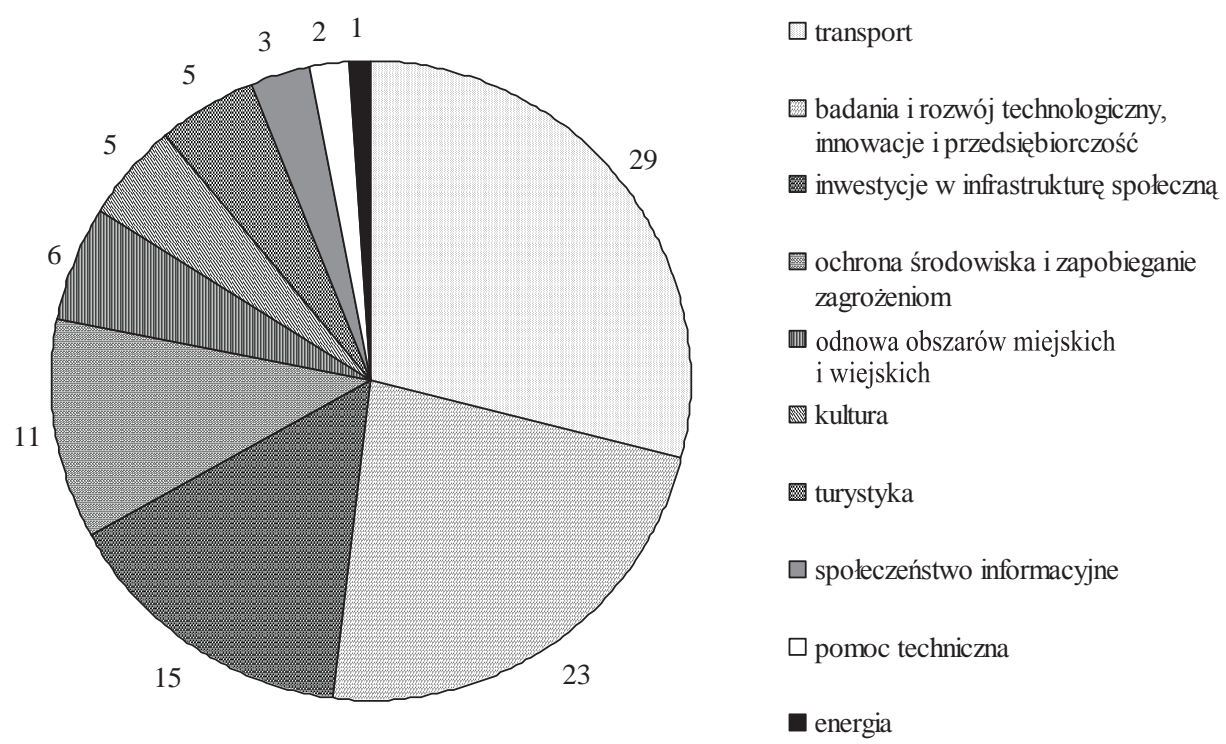

Ryc. 1. Kierunki wsparcia według zawartych umów w ramach 16 RPO - w \% (stan na 31.07.2010 r.) Źródło: opracowanie własne na podstawie Raportu rocznego... 2010

\section{DOCHODY I WYDATKI SAMORZĄDU TERYTORIALNEGO}

Struktura dochodów całego sektora jednostek samorządu terytorialnego (JST) w Polsce, według udziału poszczególnych kategorii jednostek, jest znacznie zróżnicowana. W 2010 r. największy udział w dochodach miały gminy $(44,5 \%)$ i miasta na prawach powiatu $(33,5 \%)$; zdecydowanie mniejszy powiaty $(12,6 \%)$ i województwa $(9,4 \%)$.

Dochody ogółem całego sektora JST w latach 2005-2010 charakteryzowały się stopniowym wzrostem, osiągając w 2010 r. wartość blisko 163 mld zł (ryc. 2). Jednak od roku 2006 można zaobserwować spadek rocznej dynamiki przyrostu dochodów ogółem z 14\% w 2006 r. do 8\% w 2010 r. Wzrost dochodów samorządu, szczególnie w latach 2009-2010, był determinowany napływem środków unijnych w ramach tzw. dotacji rozwojowych, tj. środków przekazanych z budżetu państwa na realizację programów unijnych (szerzej: Raport roczny..., 2010). Towarzyszył mu jednocześnie spadek poziomu dochodów własnych samorządów, wynikający z pogarszającej się koniunktury gospodarczej w kraju na skutek spowolnienia gospodarczego (ryc. 3).

Dochody własne samorządu są uzależnione od sytuacji gospodarczej w skali lokalnej. Stanowią je bowiem wpływy z podatków, opłat, sprzedaży mienia komunalnego czy dzierżawy (tzw. dochody własne podstawowe), a także wpływy z tytułu udziału w podatkach od osób fizycznych (PIT) i prawnych (CIT), stanowiących dochody budżetu państwa (Ustawa o dochodach..., 2010). Wielkość dochodów własnych samorządu, a szczególnie wysoki udział w dochodach ogółem, świadczy o zamożności JST, a także o dużej samodzielności finansowej i niezależności od transferów z budżetu państwa. 
mld zł $\quad \%$

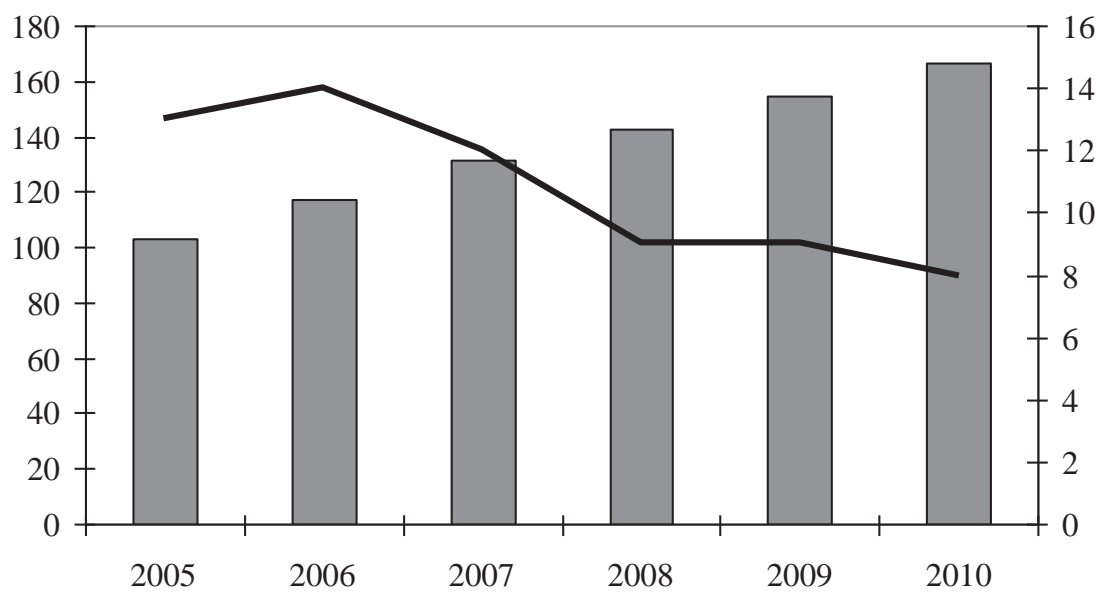

$\square$ dochody w mld zł $\quad-$ dynamika

Ryc. 2. Dochody sektora JST i dynamika w latach 2005-2010

Źródło: opracowanie własne na podstawie Raportu rocznego... (2010, 2011)

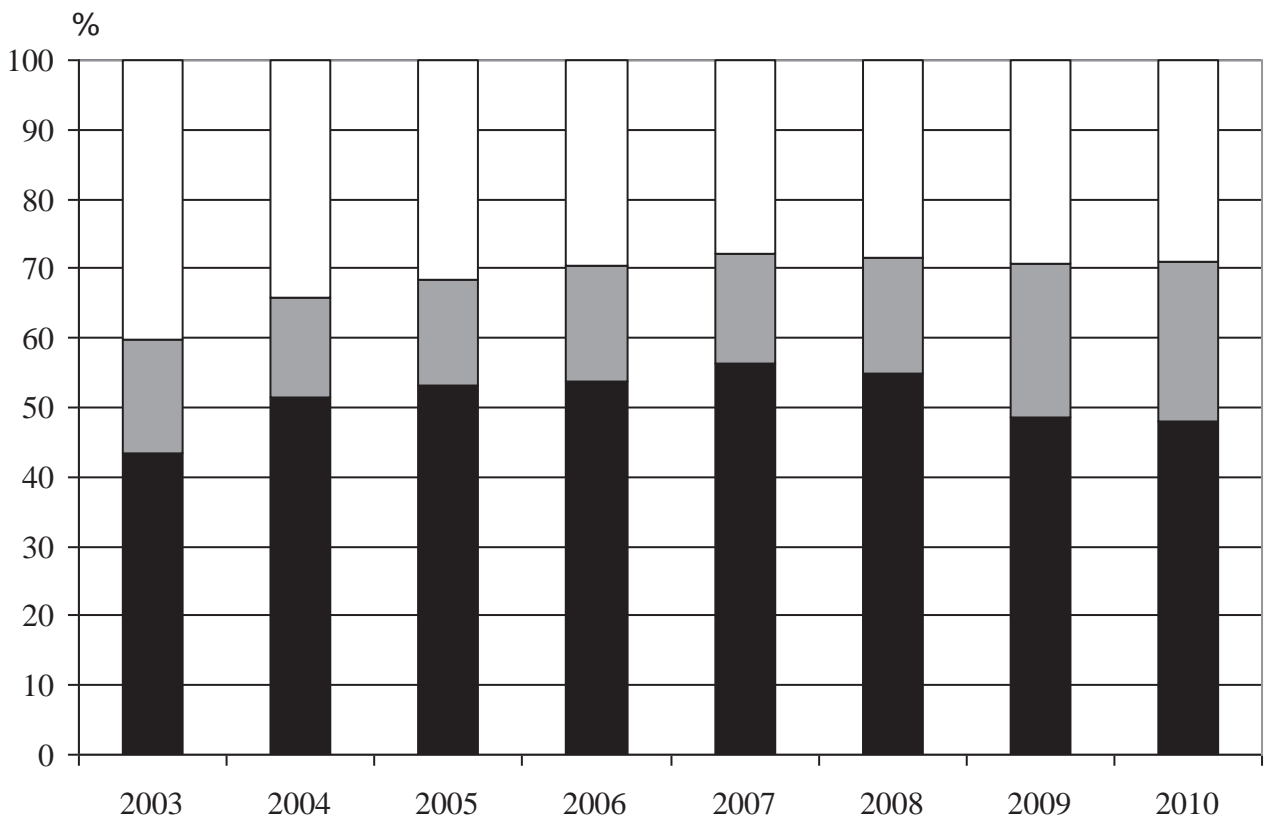

Dochody własne

$\square$ Dotacje

$\square$ Subwencje

Ryc. 3. Struktura dochodów ogółem JST w latach 2003-2010

Źródło: opracowanie własne na podstawie Raportu rocznego... (2010, 2011) 
Analiza struktury dochodów samorządu w Polsce w latach 2003-2010 wskazuje na pogarszającą się sytuację finansową JST od roku 2008. W roku tym, po wcześniejszym okresie wzrostu udziału dochodów własnych, następuje sukcesywny spadek ich udziału w latach następnych. Istotną przyczyną obniżania się ich poziomu jest m.in. spadek wpływów do budżetów JST z tytułu udziału w podatkach PIT i CIT, jako rezultat spowolnienia gospodarczego w Polsce w efekcie światowego kryzysu finansowego (ryc. 4). Szczególnie zagrożone mogą tu być budżety powiatów ziemskich i województw oraz gmin wiejskich, które są najsłabszymi ekonomicznie jednostkami w sektorze JST z uwagi na niski udział dochodów własnych w dochodach ogółem oraz wysoki udział transferów z budżetu państwa. Dotacje i subwencje, szczególnie w powiatach ziemskich i województwach, w 2010 r. stanowiły blisko 65\% ich dochodów ogółem.

\section{mld zł}

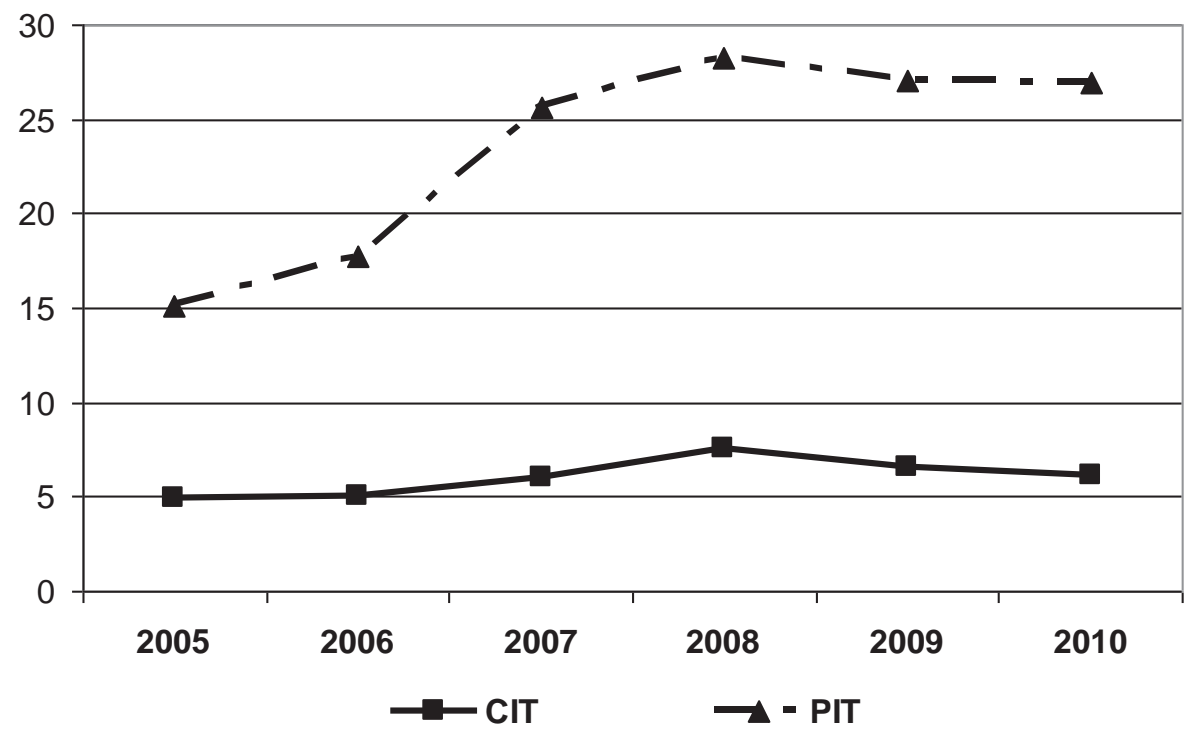

Ryc. 4. Dochody sektora JST z PIT i CIT w latach 2005-2010

Źródło: opracowanie własne na podstawie Raportu rocznego... 2010

Na pogarszającą się sytuację finansową samorządu terytorialnego w Polsce wskazują zmiany dotyczące poziomu nadwyżki operacyjnej w JST (ryc. 5). Największa nadwyżka była charakterystyczna dla gmin i miast na prawach powiatu, najniższa zaś dla powiatów i województw. We wszystkich kategoriach jednostek samorządu w latach 2008-2010 obserwujemy znaczący spadek jej poziomu. Nadwyżka operacyjna jest określana często mianem „najbardziej syntetycznej miary sytuacji finansowej bądź barometru kondycji finansowej jednostki samorządu terytorialnego". Oznacza ona dodatni wynik bieżący budżetu jednostki samorządu terytorialnego, przy czym wynik bieżący rozumiany jest jako różnica między dochodami bieżącymi a wydatkami bieżącymi budżetu. Nadwyżka operacyjna jest więc wielkością informującą o tym, ile środków finansowych pozostaje po pokryciu najważniejszych wydatków związanych z bieżącym funkcjonowaniem jednostki samorządu terytorialnego 
(Wiewióra 2008). Należy pamiętać, że zgodnie z ustawą o finansach publicznych dochodami bieżącymi są wszystkie dochody budżetowe, z wyjątkiem dotacji i środków otrzymanych na inwestycje, dochodów ze sprzedaży majątku oraz dochodów z tytułu przekształcenia prawa użytkowania wieczystego w prawo własności (Ustawa o finansach..., 2009). Istota rozumienia dochodów bieżących sprowadza się więc do uznania za nie wszystkich dochodów, które gromadzone są w sposób systematyczny i stały (nie jednorazowo lub incydentalnie). Analogicznie ustawa określa wydatki bieżące samorządu.

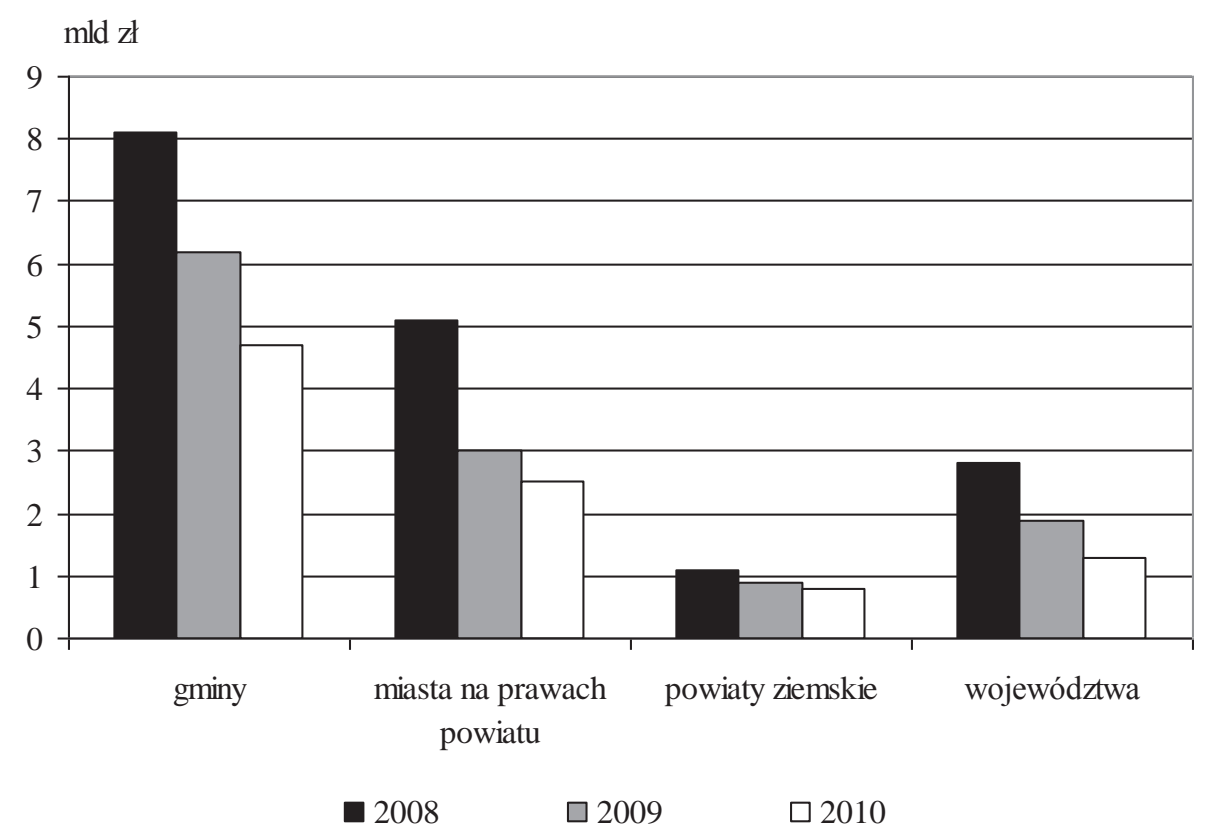

Ryc. 5. Najwyższa operacyjna w JST w latach 2008-2010

Źródło: opracowanie własne na podstawie Raportu rocznego... (2010, 2011)

Pomimo sygnałów o pogarszającej się sytuacji finansowej samorządu terytorialnego, wydatki ogółem w latach 2005-2010 wzrastały, podobnie jak dochody ogółem, ale w szybszym tempie (ryc. 6). To szybsze tempo pojawiło się ze względu na rosnące wykorzystanie środków unijnych, szczególnie po roku 2008 (ryc. 7). Ważną rolę w tych wydatkach odgrywają wydatki inwestycyjne związane z realizacją różnorodnych projektów infrastrukturalnych. Wzrost udziału tego typu wydatków odnotowały wszystkie kategorie JST, szczególnie samorządy województw (ryc. 8).

Wzrost udziału wydatków inwestycyjnych w województwach wynikał głównie z niskiego poziomu tych wydatków we wcześniejszych okresach. Niższy udział wydatków inwestycyjnych w wydatkach miast na prawach powiatu czy gmin był efektem szerszej skali innych wydatków budżetowych realizowanych przez te jednostki w związku z przypisanymi zadaniami. 


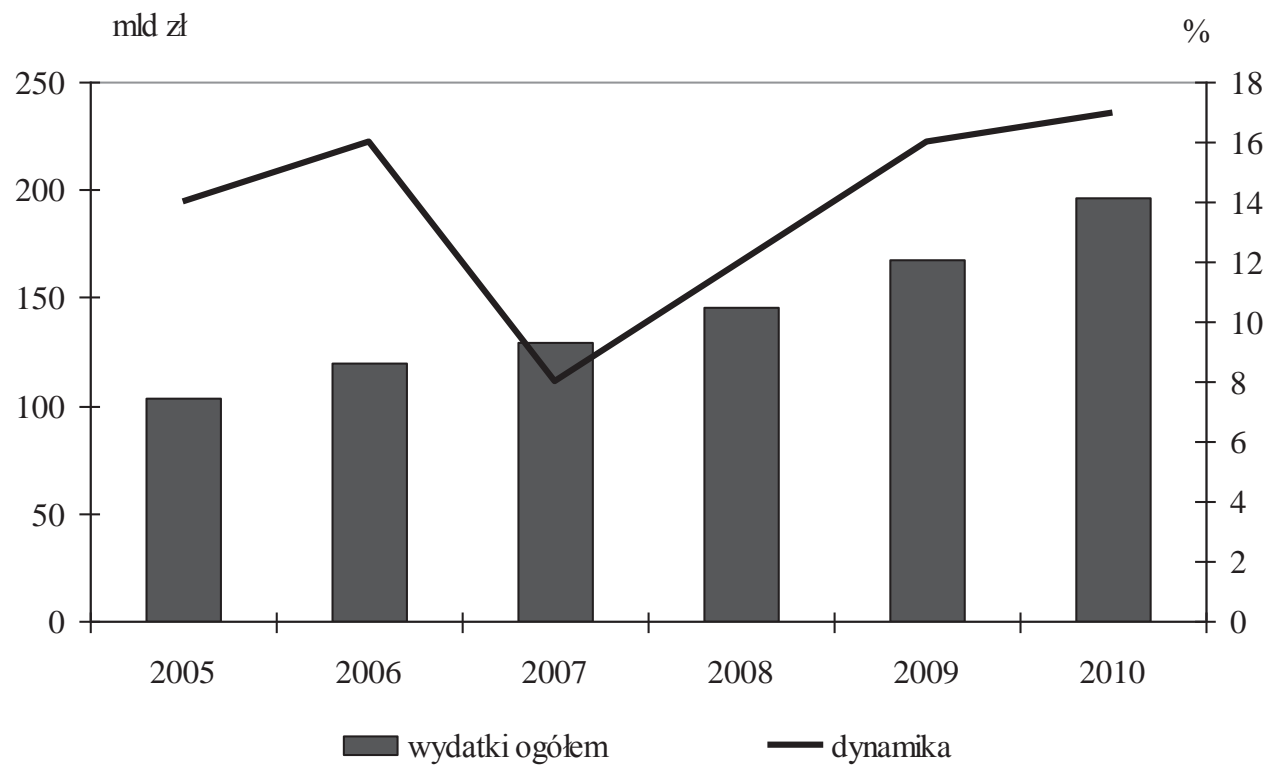

Ryc. 6. Wydatki ogółem sektora JST i dynamika w latach 2005-2010

Źródło: opracowanie własne na podstawie Raportu rocznego... (2010, 2011)

mld zł

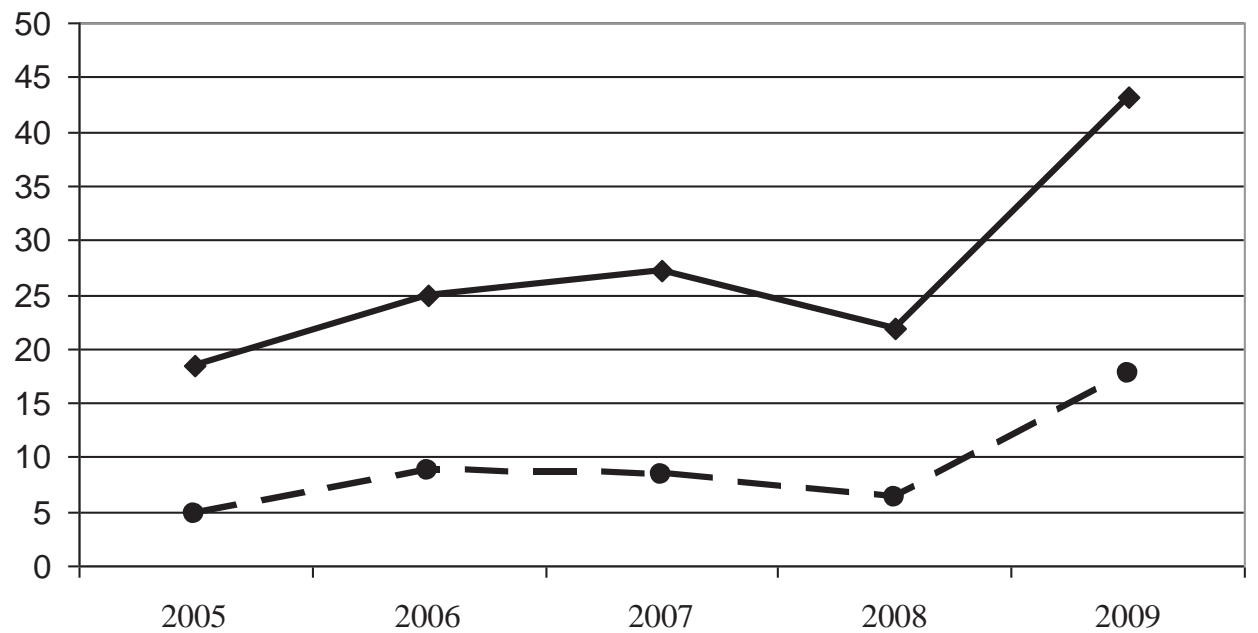

$\longrightarrow$ wydatki majątkowe $\longrightarrow$ - wydatki związane z realizacją projektów unijnych

Ryc. 7. Wydatki majątkowe i związane z realizacją projektów unijnych w sektorze JST w latach 2005-2009

Źródło: opracowanie własne na podstawie Raportu rocznego... 2010 
Miasta na prawach powiatu nadal jednak pozostają najbardziej znaczącym inwestorem w sektorze JST. Świadczy o tym stopień koncentracji inwestycji zrealizowanych przez 65 miast na prawach powiatu w 2009 r., wynoszący ponad 12 mld zł, co stanowiło 30\% wszystkich inwestycji w sektorze JST, wobec inwestycji o wartości 16 mld zł (39\% ogółu) zrealizowanych przez blisko 2,4 tys. gmin. W przypadku samorządów województw udział ten wyniósł 23\%, zaś powiatów niespełna 10\% (Raport roczny..., 2010).

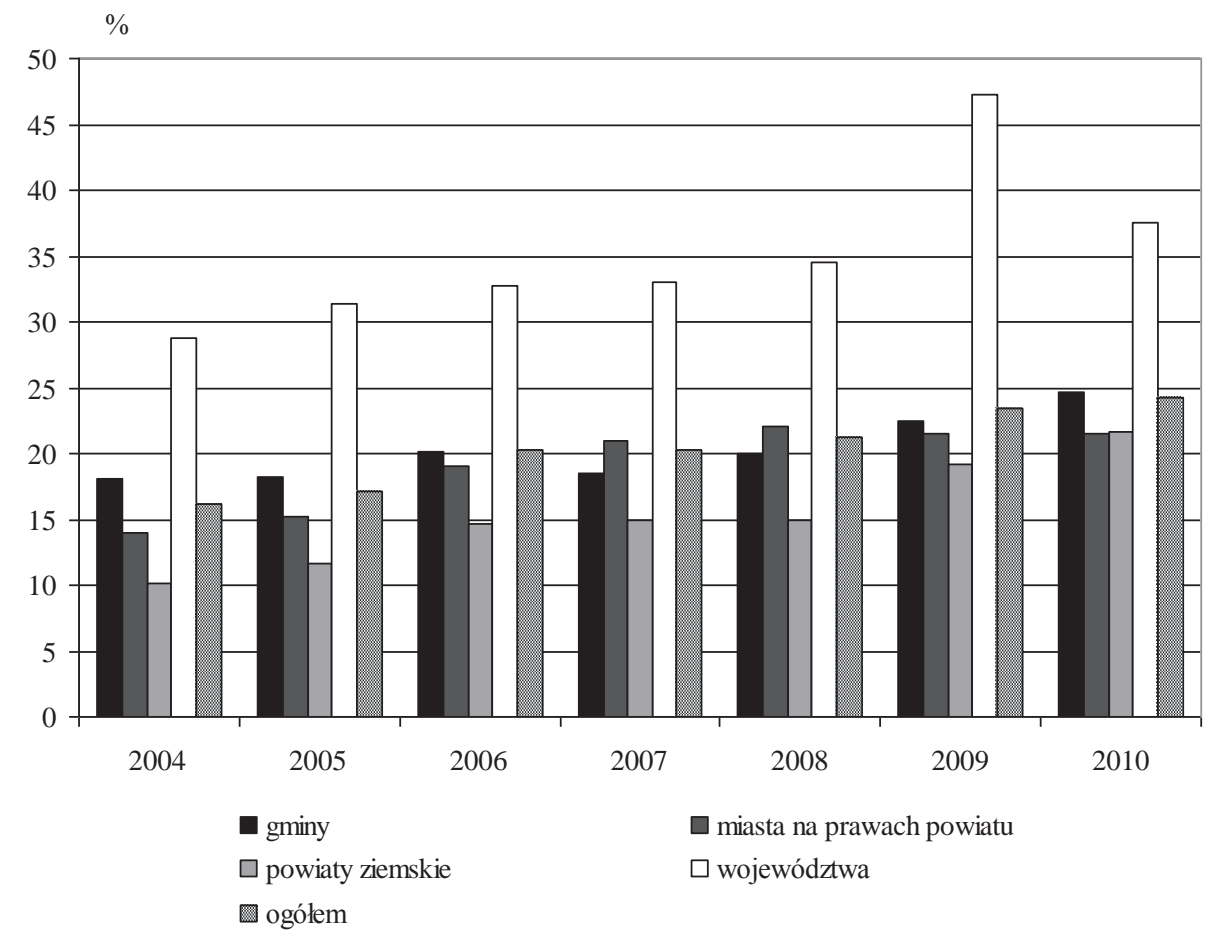

Ryc. 8. Udział wydatków inwestycyjnych w wydatkach ogółem w latach 2004-2010 w poszczególnych kategoriach JST

Źródło: opracowanie własne na podstawie Raportu rocznego... (2010, 2011)

\section{WYNIKI BUDŻETÓW I ZADŁUŻENIE SAMORZĄDU TERYTORIALNEGO}

Niższe tempo przyrostu dochodów w porównaniu z wydatkami skutkuje narastającym deficytem budżetowym w samorządach. Jest on charakterystyczny dla wszystkich kategorii jednostek samorządu, lecz szczególnie głęboki w miastach na prawach powiatu i gminach (ryc. 9). Wielkość deficytu budżetowego w tych jednostkach jest podyktowana nie tylko skalą inwestycji, ale także szerokim zakresem zadań i niewystarczającą ilością środków finansowych. Rezultatem powyższej sytuacji jest postępujący proces zadłużania się samorządu w latach 2005-2010. 
$\operatorname{mln} \mathrm{zk}$

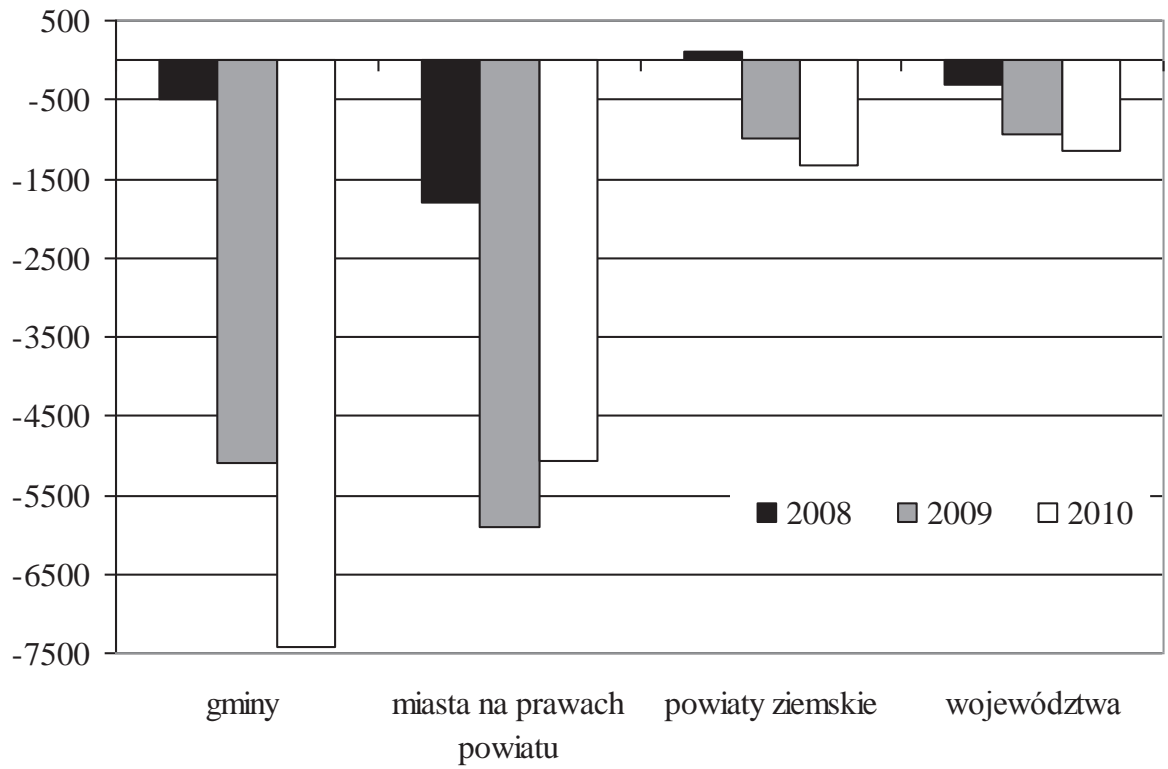

Ryc. 9. Wyniki budżetów JST w latach 2008-2010

Źródło: opracowanie własne na podstawie Raportu rocznego... (2010, 2011)

Szczególnie szybkie roczne tempo przyrostu zadłużenia w JST nastąpiło po roku 2007: z 5\% do 35\% w roku 2010 (ryc. 10). Proces ogólnego wzrostu zadłużenia samorządu terytorialnego korespondował z tempem zadłużania się poszczególnych jego kategorii. Największa jednak skala zadłużenia dotyczyła miast na prawach powiatu i gmin, które najmocniej odczuły spadek dochodów własnych związanych ze spowolnieniem gospodarczym. Analiza danych w 2010 r. wskazuje, że samorządy wykorzystują najczęściej kredyty i pożyczki (86,7\%) dla uzupełnienia swoich budżetów, chociaż coraz większego znaczenia nabiera rynek obligacji komunalnych (12,9\%) (Raport roczny..., 2011).

Biorąc pod uwagę skalę realizowanych przez samorządy inwestycji i konieczność utrzymania bieżących wydatków wynikających z przypisanych zadań, należy oczekiwać dalszego wzrostu zadłużania się sektora JST. Pomimo znaczącego wzrostu, wskaźnik zadłużenia JST, mierzony relacją udziału zobowiązań do dochodów ogółem, wyniósł w 2010 r. dla całego sektora samorządu terytorialnego $33,8 \%$. Oznacza to, że nie wykazuje zagrożenia przekroczenia ustawowo dozwolonej granicy $60 \%$. Omawiany wskaźnik był jednak zacznie zróżnicowany w układzie poszczególnych kategorii JST. Najwyższy poziom zadłużenia miały miasta na prawach powiatu (43,5\%), następnie województwa (30,4\%), gminy (30,3\%), najniższy zaś był charakterystyczny dla powiatów i wynosił $24,2 \%$.

Mimo przewidywanego dalszego wzrostu poziomu zobowiązań dla całego sektora samorządu stan zadłużenia nie będzie stanowił zagrożenia dla sytuacji finansowej JST. Może jednak w jednostkowych przypadkach mieć wpływ na płynność finansową, a zatem na spłatę zobowiązań niektórych samorządów. Dotyczyć to może jednostek, których dochody zależą 
od wpływów podatkowych od firm działających na ich terenie, w sytuacji utrzymującej się nadal dekoniunktury gospodarczej. Rezultatem trudniejszej sytuacji finansowej samorządów może być także ograniczenie skali inwestycji, ale przede wszystkim projektów, które nie są finansowane ze środków unijnych.

mld zł

$$
\%
$$

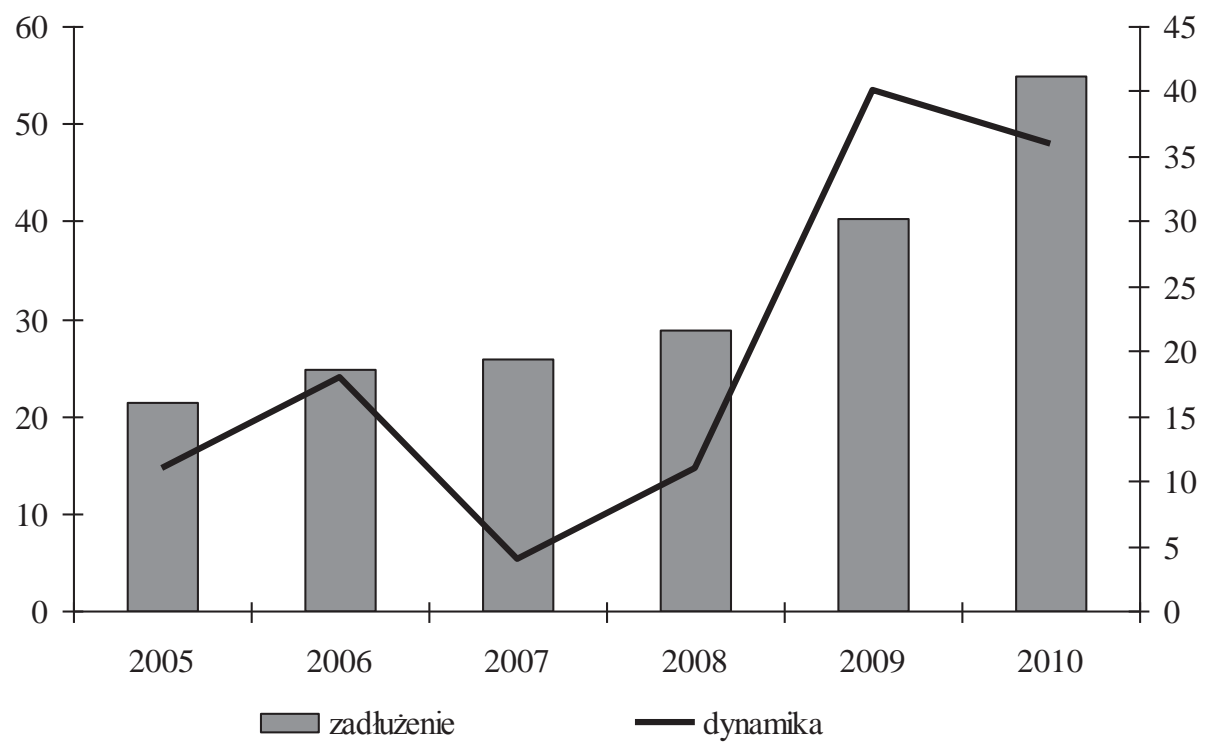

Ryc. 10. Stan zadłużenia sektora JST i dynamika w latach 2005-2010

Źródło: opracowanie własne na podstawie Raportu rocznego... (2010, 2011)

\section{ZRÓŻNICOWANIE PRZESTRZENNE DOCHODÓW I WYDATKÓW W GMINACH}

Analizę zróżnicowania przestrzennego gmin w Polsce pod względem dochodów i wydatków przeprowadzono odnosząc ich wielkość do liczby mieszkańców. Porównanie tego wskaźnika pozwala na określenie poziomu zamożności JST. Wysokość tego wskaźnika świadczy o pozytywnej sytuacji finansowej jednostki terytorialnej, ale należy zbadać czy jest ona wynikiem dochodów własnych danego samorządu, czy też wysoka wartość dochodów na mieszkańca jest rezultatem wielkości transferów z budżetu państwa.

Pod względem wartości dochodów ogółem per capita gminy w Polsce są bardzo zróżnicowane. Porównując średnią dochodów ogółem w gminach na mieszkańca w grupach decylowych możemy zauważyć, iż 60\% gmin uzyskuje wartość dochodów niższą od przeciętnej krajowej. Dodatkowo średnia dochodów gmin z pierwszej grupy decylowej w 2009 r. była niższa o 93\% od średniej w grupie dziesiątej. Podobne skrajności miały miejsce w rozkładzie wydatków ogółem. Potwierdzeniem tego dużego zróżnicowania jest także wielkość dochodów JST na mieszkańca gmin w układzie województw (ryc. 11A). Najwyższe wartości bada- 
nego parametru w 2009 r. występowały w województwach: mazowieckim, śląskim, pomorskim i dolnośląskim; najniższe zaś wartości występowały w województwach południowowschodniej Polski: świętokrzyskim, podkarpackim i lubelskim, a także w opolskim. Słabość finansową gmin województw podkarpackiego i lubelskiego potwierdza także struktura dochodów. Udział dochodów własnych w dochodach ogółem gmin tych województw kształtował się na poziomie najniższym w kraju i wynosił poniżej 40\% (ryc. 11B). Najkorzystniejsza sytuacja pod względem udziału dochodów własnych w dochodach ogółem charakteryzowała województwa: mazowieckie, śląskie i dolnośląskie. Pomimo relatywnie niższych wartości dochodów ogółem na mieszkańca w województwach zachodniopomorskim, wielkopolskim, łódzkim, małopolskim czy (szczególnie) opolskim, województwa te cechowały się zdecydowanie wyższym udziałem dochodów własnych, co bez wątpienia świadczy o ich lepszej kondycji finansowej niż by to wynikało z wartości wskaźnika dochodów ogółem na mieszkańca.
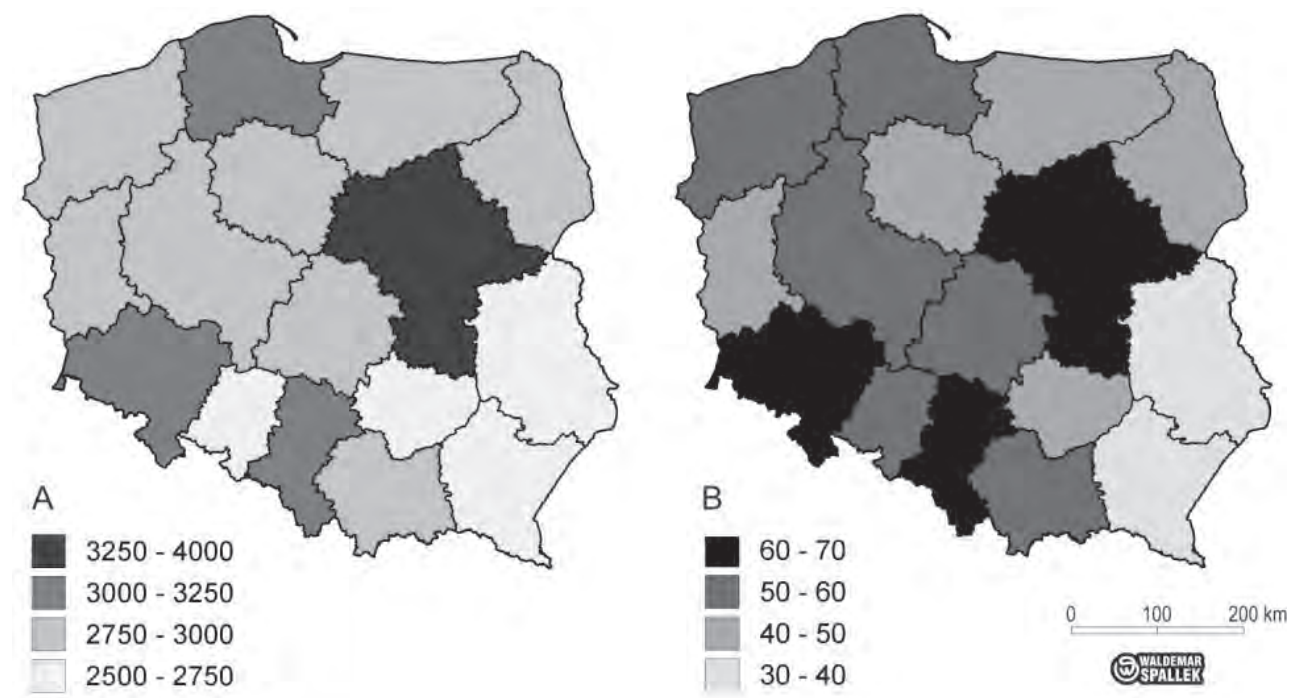

Ryc. 11. Dochody ogółem w zł na mieszkańca (A) i udział dochodów własnych w zł ogółem (B) w JST w 2009 r.

Źródło: opracowanie własne na podstawie Banku Danych Lokalnych

Gminy są również bardzo zróżnicowane pod względem udziału dochodów własnych w zależności od ich typu. Najsilniejszymi finansowo jednostkami samorządu terytorialnego są zdecydowanie gminy miejskie, najsłabszymi zaś gminy wiejskie (ryc. 12A i 12C). Warto zwrócić uwagę, iż w przypadku tych pierwszych najniższa klasa udziału dochodów własnych jest najwyższą klasą udziału w tych drugich. Cechą charakterystyczną przestrzennego rozkładu omawianej cechy jest także to, że jej wartość obniża się w kierunku wschodnim, bez względu na kategorię poziomu zamożności JST. Najniższy udział dochodów własnych w dochodach ogółem w 2009 r. występował w gminach wiejskich województw: lubelskiego, świętokrzyskiego, podkarpackiego, a także małopolskiego. 
Duże, przestrzenne zróżnicowanie dochodów gmin jest silnie uzależnione od położenia względem układów metropolitalnych. Jego efektem jest znaczna polaryzacja intraregionalna województw, na obszarze których występują największe aglomeracje miejsko-przemysłowe. Powyższa zależność jest szczególnie widoczna na przykładzie województwa mazowieckiego, gdzie najwyższe dochody na mieszkańca oraz najwyższy udział dochodów własnych jest charakterystyczny przede wszystkim dla Warszawy i jej strefy aglomeracyjnej przy zdecydowanie uboższych gminach peryferyjnych regionu (por. ryc. 11A i B oraz ryc. 12C).
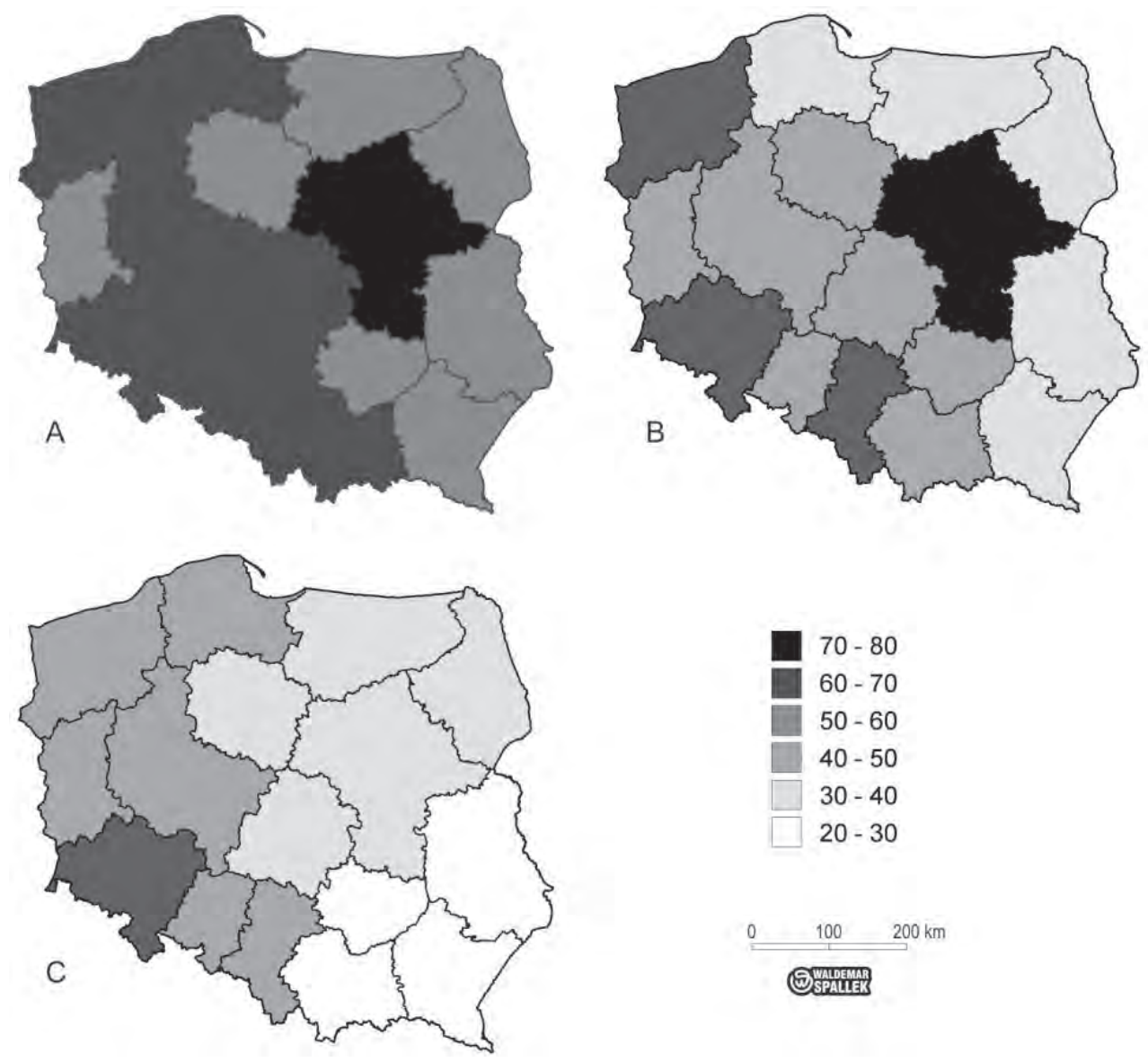

Ryc. 12. Udział procentowy dochodów własnych w dochodach ogółem w gminach miejskich (A), w gminach miejsko-wiejskich (B) i w gminach wiejskich (C) w 2009 r.

Źródło: opracowanie własne na podstawie Banku Danych Lokalnych

Cechą charakterystyczną praktycznie wszystkich gmin w Polsce są wyższe wydatki ogółem na mieszkańca niż uzyskiwane dochody. Oprócz województwa opolskiego, wszystkie województwa „przesuwają się” do wyższych klas wydatków inwestycyjnych na mieszkańca w stosunku do dochodów (por. ryc. 11A i 13). 

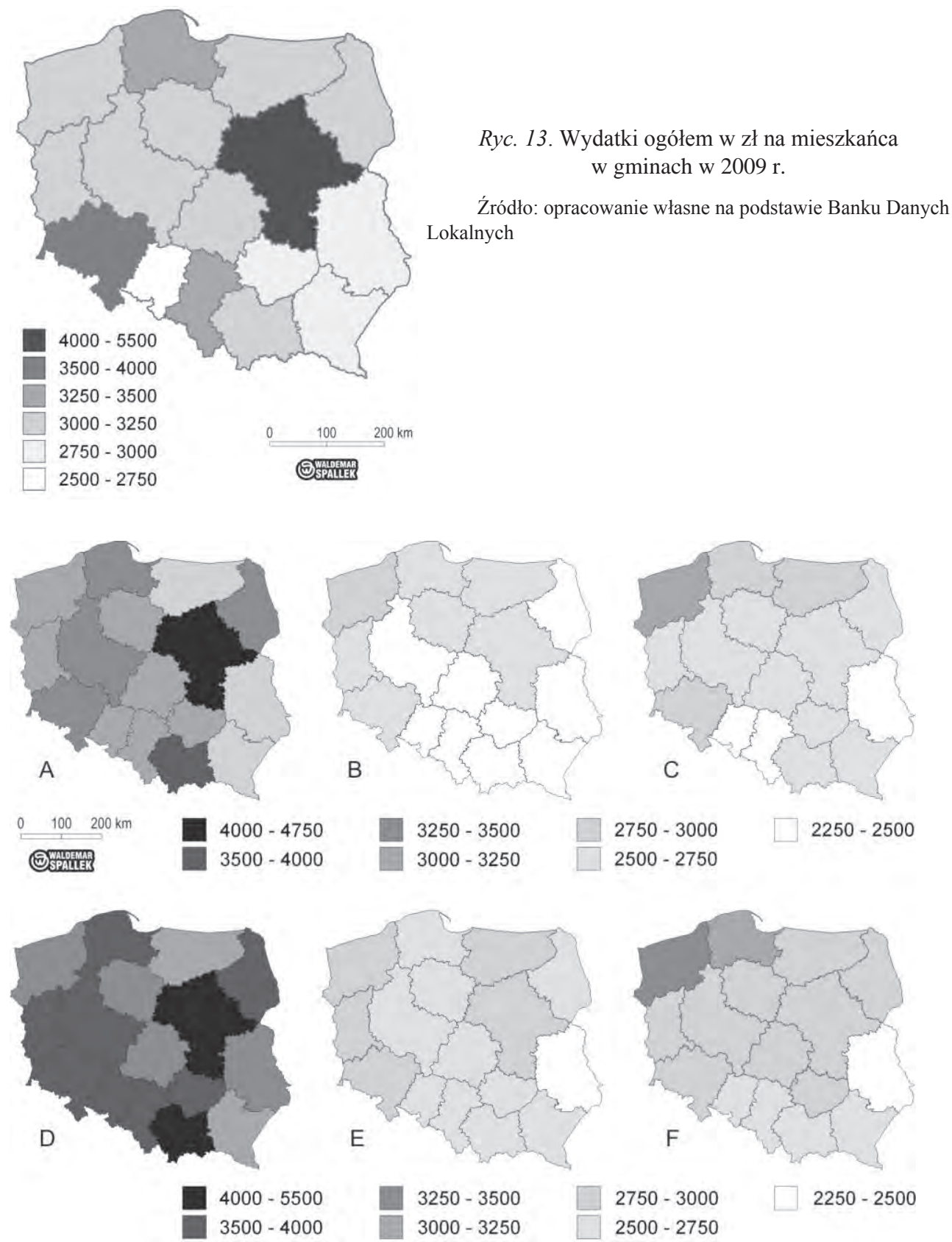

Ryc. 14. Dochody ogółem w zł na mieszkańca w gminach miejskich (A), w gminach miejsko-wiejskich (B), w gminach wiejskich (C) oraz wydatki ogółem w zł na mieszkańca w gminach miejskich (D), w gminach miejsko-wiejskich (E), w gminach wiejskich (F) w 2009 r.

Źródło: opracowanie własne na podstawie Banku Danych Lokalnych 
Podobnie jak w przypadku dochodów ogółem, wydatki ogółem na mieszkańca w gminach są zróżnicowane pod względem ich typu. Jednak w przypadku wydatków te zróżnicowania nie są aż tak wyraźne (ryc. 14). Najwyższe występują przede wszystkim w gminach miejskich, gdyż mają one zdecydowanie największe możliwości finansowe i dokonują przeciętnie największych wydatków inwestycyjnych. Zwraca jednak uwagę stosunkowo wysoki poziom wydatków ogółem na mieszkańca w wiejskich gminach dwóch województw nadmorskich: zachodniopomorskiego i pomorskiego (ryc. 14F). W tym przypadku jest to efektem wysokiej aktywności inwestycyjnej nadmorskich ośrodków turystycznych o dobrej kondycji finansowej, funkcjonujących w przeważającej większości w obrębie gmin wiejskich.

\section{Podsumowanie}

Analiza kondycji finansowej samorządu terytorialnego w Polsce wskazuje na pogarszanie się wyników operacyjnych JST, tj. obniżanie się poziomu środków własnych, co przy spodziewanych wysokich wydatkach inwestycyjnych związanych z realizacją projektów unijnych rodzi duże prawdopodobieństwo dalszego wzrostu poziomu ich zadłużenia. Cechą charakterystyczną samorządu w Polsce jest także silne zróżnicowanie poziomu dochodów i wydatków gmin. Kondycja finansowa JST jest uzależniona od ich potencjału gospodarczego (poziom dochodów własnych, PIT, CIT), a istotny wpływ na poziom ich dochodów w ostatnich latach mają środki przekazywane na realizację projektów unijnych. Szczególnie zagrożone są budżety powiatów ziemskich, województw oraz gmin wiejskich, które w wysokim stopniu są uzależnione od transferów z budżetu państwa, a miasta na prawach powiatu z uwagi na swój potencjał nadal pozostają najbardziej znaczącym inwestorem wśród JST. Zagrożeniem dla całego sektora JST pozostaje stan finansów publicznych. Szczególne znaczenie ma niebezpieczeństwo przekroczenia drugiego progu ostrożnościowego, tj. 55\% długu publicznego w stosunku do PKB, który w 2010 r. wyniósł już 54,9\%. Mimo że zadłużenie samorządu terytorialnego na koniec 2009 r. stanowiło jedynie 3\% długu publicznego, przekroczenie wspomnianego progu skutkuje niemożnością dalszego zadłużania się (Raport roczny..., 2010). Jego efektem może być zmniejszenie aktywności inwestycyjnej wszystkich jednostek samorządu terytorialnego w Polsce.

\section{Literatura}

Brezdeń P., Drozdowska J., Spallek W., 2010, Wybrane instytucje prorozwojowe zwiazane z pomoca publiczna $w$ aktywizacji polskiej gospodarki, [w:] Procesy transformacji przemystu i ustug $w$ regionalnych $i$ krajowych ukladach przestrzennych, red. Z. Zioło, T. Rachwał, Prace Komisji Geografii Przemysłu PTG, Nr 15, Warszawa-Kraków, s. 235-257.

Domański R., Marciniak A., 2003, Sieciowe koncepcje gospodarki miast i regionów, KPZK PAN, Studia t. 113, Warszawa.

Florida R., 2000, The Learning Region, [w:] Regional Innovation, Knowledge and Global Change, Z.J. Acs, (ed.), Pinter, New York.

Raport roczny 2010. Sytuacja finansowa jednostek samorzadu terytorialnego, 2010, Departament Strategii i Analiz, PKO BP SA, Warszawa. 
Raport roczny 2011. Sytuacja finansowa jednostek samorzadu terytorialnego, 2011, Departament Strategii i Analiz, PKO BP SA, Warszawa.

Romanowski R., 2011, Rola jednostek samorzadu terytorialnego w kreowaniu polityki innowacyjnej, ris.warmia.mazury.pl/.../2_rola_jst_w_kreowaniu_procesu_innowacyjnego.ppt, dostęp: 08.12.2011 r.

Ustawa o dochodach jednostek samorzadu terytorialnego z dnia 13 listopada 2003 r., Dz. U. z 2010 r. Nr 80, poz. 526.

Ustawa o finansach publicznych z dnia 27 sierpnia 2009 r., Dz. U. z 2009 r. Nr 157, poz. 1240, tekst jednolity.

WiewióraM.,2008,http://www.samorzad.pap.pl/palio/html.run?_Instance=cms_samorzad.pap.pl\&_Pa geID $=2 \& s=$ depesza\&dz=lewa_szpalta.wolters\&dep $=45334 \&$ data $=\& \_C h e c k S u m=1774212395$, dostęp: 08.12.2011 r.

\section{Adresy internetowe}

http://www.stat.gov.pl/bdl/app/strona.html?p_name=indeks, dostęp: 08.12.2011 r. Paweł Brezdeń

\section{Financial condition of local government in Poland as a factor stimulating the innovation of economy}

The paper focuses on the financial situation of local government units in Poland in 2005-2010. It presents the results of operational issues relating to local government, based on the implementation of budgets and structures relating to: income, expenditure, main investment expenditure, debt, and budget deficit. Analysis was conducted for all levels of local government (commune-gmina, district - powiat, province/voivodship - województwo) and its various types (urban commune, urban-rural commune and rural commune, county and town with the rights of a county).

dr Paweł Brezdeń

Uniwersytet Wrocławski

Instytut Geografii i Rozwoju Regionalnego

Zakład Analiz Regionalnych i Lokalnych

e-mail: pawel.brezden@uni.wroc.pl

dr Waldemar Spallek

Uniwersytet Wrocławski

Instytut Geografii i Rozwoju Regionalnego

Zakład Kartografii

email: waldemar.spallek@uni.wroc.pl 